\title{
Developing students' competences in project management in Poland - a case study of IPMA- Student Certification
}

\author{
Joanna Rzempała \\ University of Szczecin, Faculty of \\ Management and Economics of \\ Services \\ Szczecin, Poland \\ joanna.rzempala@wzieu.pl \\ ORCID 0000-0002-0542-9370
}

\begin{abstract}
This article presents experiences and early conclusions from the Polish certification dedicated to students in the field of project management. First of all, it describes the IPMA - Student Competence Model. Secondly, it presents the results of student certification, the level of competence in particular areas and the increase of interest in certification in particular years. Finally, it formulates some preliminary conclusions and recommendations for further improvement of PM education. The research sample includes students from 10 Polish universities participating in the IPMA Student Programme.
\end{abstract}

Keywords-competences, project management, certification, student competences, formal and informal education.

\section{INTRODUCTION}

As more and more organisations adopt a project management approach and the demand for project managers increases, so does the interest in project managers' competence and standards of development and assessment of project management competence. Project management standards are used worldwide in training and development, professional certification programs and project management methodologies.[1] In the Manpower Report "Solving the Talent Shortage Build, Buy, Borrow and Bridge" [2], the project manager was ranked eighth, behind such professions as: drivers, engineers and financial and IT employees. It is worth noting that the combination of technical and project management skills can give a clear advantage in the competitive labour market.

\section{DEFINITION OF COMPETENCE}

The notion of competence appears in different ways. However, two of them are dominating: organisational and individual approach.

Generally speaking, this approach reflects a person's ability to perform a certain task of the role. Acting on behalf of the company, the employee uses his or her labour competences.

Professional competence is the basic characteristic of a person required to fulfil a professional role in an effective way or above average. Basic characteristic may be motivation, attribute, ability, self-image or role aspect of the social skills or knowledge which the person possesses and uses [3]. Competence is the essential characteristic of a person who has a causal relationship with the person being assessed by reference to the following criteria effectiveness or above-average performance in professional situations [4]. Competences are qualities of a person who makes use of them in a proper and consistent way to achieve the expected results. These include knowledge, skills, certain aspects of self-perception, social behaviour, character traits, thought patterns, attitudes and ways of thinking, feeling and acting [5].

While comparing the definitions of competence we can notice that some of them focus on the measurement of effects for the company, some relate only to the individual perspective.

\section{FORMAL AND INFORMAL EDUCATION}

Competence management is a deliberate, systematic and methodical adaptation of knowledge, skills and attitudes of employees to the objectives of the organisation; and using them in accordance with these purposes. In the case of students and graduates we are talking about adapting their competences to the requirements and needs of the labour market [6].

The basis for the management of students' competences at universities is the Educational Effects Matrix, which includes knowledge, skills and social competences of students from particular fields of study. They are a combination of elements of knowledge and technical and social skills in particular fields of study. The scope of education, including the didactic process is a formal improvement resulting from the implementation of the curricula in a given field of study. Improvement of students' competences is also implemented through non-formal learning [7]. Systematic implementation, e.g. in the form of additional courses and training, activities in science clubs, academic and professional associations. Making it possible for students to undertake such activities can significantly increase their value on the labour market. The activity of universities in the area of initiating 
cooperation with business environment institutions, employers' associations and professional associations is, therefore, an added value that students receive within the implementation of the basic course of studies. The possibility of getting knowledge of work conditions in a given branch or profession, market expectations concerning the professional competences sought or direct involvement in initiatives implemented by professional associations is an opportunity to access the labour market in a faster and more effective way.

\section{IPMA-STUDENT CERTIFICATION}

The project management has been moving towards professionalisation through certification. Today, there are more than one million certified project managers worldwide (number complied from statistics provided at PMI.org and IPMA.world sites) [8].

In Poland cooperation between universities and business, with the support of IPMA Poland a professional project management association, allowed to develop a competence model for students a set of competences, which on one hand are sought after by the labor market related to project management, and on the other hand encompass possibilities of education and practical preparation within the framework of educational programmes at universities. The competence groups derived from the ICB 3.0 Model, which students and graduates of universities should have to be prepared to work in project teams after graduation (Table 1). With the change of the ICB competence model from version 3.0 to version 4.0, the IPMA Student model is transformed and adapted.

In the ICB 3.0, there are three groups of competences: [9]

- technical competences which consist of specific methods, tools and techniques used by professionals in projects,

- behavioural competences deal with personal relations between individuals and group, managed in the project,

- contextual competences deal with the interaction of the project team within the context of the project.

The IPMA-Student Programme has been in operation since 2014, and so far it has been implemented at 25 faculties of universities in Poland, out of which 10 organise IPMA-Student certification exams, so there are already grounds for verifying the effectiveness of students' education based on the model.

Universities which are partners in the IPMAStudent Programme and apply for accreditation of their faculties and specialisations, have to demonstrate that they conduct at least 60 hours of project management classes by the IPMA-Student competence model in full-time or extramural studies within the framework of educational programmes. The faculties that have applied for accreditation are management, economic and technical faculties.

It is worth noting that among the universities which were granted IPMA-Student accreditation, apart from those which only confirmed compliance of their curricula with the requirements of IPMA-Student, there were also universities which had launched new curricula based on IPMA-Student's educational results.

Students taking IPMA Student exams should complete an accredited course or take advantage of dedicated project management courses. The university coordinator for IPMA Student is a person who confirms the student's preparation for the IPMA Student examination (completion of the accredited course) and supervises the examination sessions.

TABLE I. COMPETENCE ELEMENTS IN IPMA-STUDENT MODEL

\begin{tabular}{|c|c|c|}
\hline $\begin{array}{l}\text { Technical } \\
\text { competence } \\
\text { elements }\end{array}$ & $\begin{array}{c}\text { Behavioural } \\
\text { competence } \\
\text { elements }\end{array}$ & $\begin{array}{c}\text { Contextual } \\
\text { competence } \\
\text { elements }\end{array}$ \\
\hline $\begin{array}{l}\text { 1.01 Project } \\
\text { management } \\
\text { success } \\
1.02 \text { Interested } \\
\text { parties } \\
1.03 \text { Project } \\
\text { requirements \& } \\
\text { objectives } \\
1.04 \text { Risk \& } \\
\text { opportunity } \\
1.05 \text { Quality } \\
1.06 \text { Project } \\
\text { organisation } \\
1.07 \text { Teamwork } \\
1.08 \text { Problem } \\
\text { resolution } \\
1.09 \text { Project } \\
\text { structures } \\
1.10 \text { Scope \& } \\
\text { deliverables } \\
1.11 \text { Time \& } \\
\text { project phases } \\
1.12 \text { Resources } \\
1.13 \text { Cost \& } \\
\text { finance } \\
1.15 \text { Changes } \\
1.16 \text { Control \& } \\
\text { reports } \\
1.18 \\
\text { Communication } \\
1.19 \text { Start-up } \\
1.20 \text { Close-out }\end{array}$ & $\begin{array}{l}\text { 2.01 Leadership } \\
\text { 2.02 Engagement } \\
2.04 \\
\text { Assertiveness } \\
\text { 2.07 Creativity } \\
\text { 2.08 Results } \\
\text { orientation } \\
\text { 2.09 Efficiency } \\
\text { 2.12 Conflict \& } \\
\text { crisis } \\
\text { 2.13 Reliability } \\
\text { 2.14 Values } \\
\text { appreciation } \\
\text { 2.15 Ethics }\end{array}$ & $\begin{array}{l}\text { 3.01 Project } \\
\text { orientation } \\
\text { 3.05 Permanent } \\
\text { organisation } \\
\text { 3.08 Personnel } \\
\text { management }\end{array}$ \\
\hline
\end{tabular}

Programme.

The IPMA Student competence elements are a subset of the competences of the ICB model; differences relate to the scope and level of competence. The following description is used to determine the competence level:

1/Knowledge (knowledge of terms, definitions, models, facts, criteria, standards, methods, processes, relationships); 
2/Understanding (ability to interpret terms, definitions, models, facts, criteria, standards, methods, processes, relationships);

3/Skill - "simple" application (for a specific scenario) recognition and use of appropriate methods, techniques and tools, interpretation results, conclusions);

4/ Skills - 'Complex' application (for a specific scenario, linking different areas and criteria, choosing the right method, techniques, etc. and tools, interpretation of results and selection of the best solution) - a level not required for IPMA Student certification.

\section{STUDENT COMPETENCE DEVELOPMENT - CERTIFICATION RESULTS}

The data came from the IPMA-Student portal, from the results of the exam in an electronic form.

These are universities of different profiles. This group includes universities, business schools and technical universities. Students covered by the study come from various fields and specialisations .e. both management and technical fields of study I or II degree of full-time studies.

MS Excel 2013 software was used to prepare the results of the analysis. Basic statistical analyses were performed.Source: Own elaboration based on materials of the IPMAStudent Programme.

Fig. 1 shows the number of exams each year, from the first year of the project to the first quarter of 2019. It shows the increasing number of students interested in IPMA Student examinations (Source: Own elaboration based on materials of the IPMA-Student Programme.

Fig. 1). The numbers of exams include both paper and e-exams. The following tests are based on electronic certification exams.

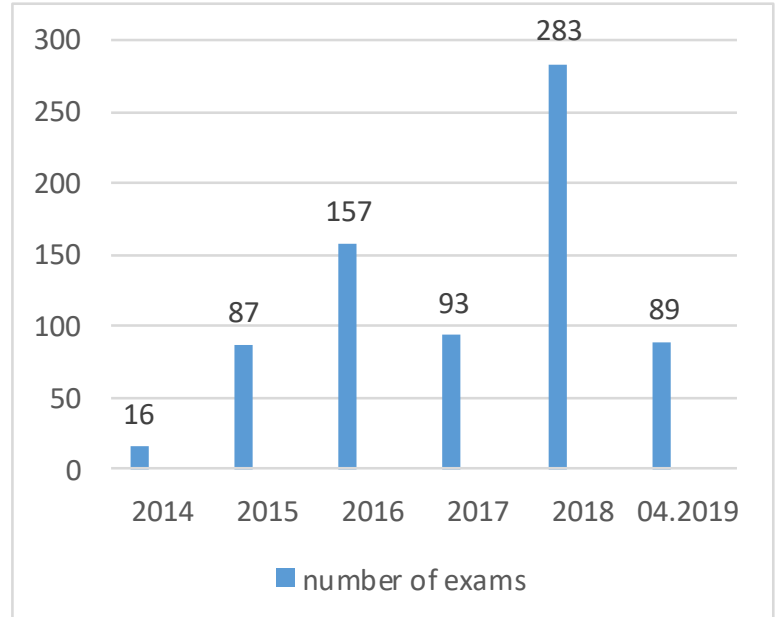

Source: Own elaboration based on materials of the IPMA-Student Programme.

Fig. 1. A trend indicating increased interest of students in improving competences based on the IPMA-Student Model

The research sample includes students from 10 accredited universities that have conducted IPMA
Student electronic certification exams (some universities use the paper version). These are universities of different educational profiles. This group includes both universities, business schools and technical universities. Students covered by the study represent different fields of study, as well as specialisations, i.e. those related to management and technical fields of study, as well as full-time studies of I or II degree (291 people in total).

Data of student examination results come from the electronic examination platform - IPMA-Student portal. MS Excel 2013 software was used to prepare the results.

TABLE II. IPMA-STUDENT EXAM RESULTS

\begin{tabular}{|l|c|}
\hline \multicolumn{1}{|c|}{ Item } & e-Exam IPMA-Student \\
\hline Total number of exams taken & 291 \\
\hline $\begin{array}{l}\text { Average assessment of all } \\
\text { exams taken }\end{array}$ & $61 \%$ \\
\hline Median & $61 \%$ \\
\hline Standard Deviation & $9 \%$ \\
\hline Asymmetry coefficient & $-0,14$ \\
\hline Kurtosis & $-0,3$ \\
\hline Internal cohesion coefficient & $77 \%$ \\
\hline Source: Own elaboration based on materials of the IPMA-Student
\end{tabular}
Programme.

The distribution of the results obtained in the IPMA Exam is presented in Diagram 1. The minimum score in the scale of 100 is 36 ; the maximum is 81 (Table 2). The distribution of the results is approximated according to the normal distribution. The median and mean value are the same, which indicates the symmetry of the distribution.

TABLE III. INDICATOR OF CORRECT ANSWERS TO QUESTIONS IN PARTICULAR AREAS OF IPMA COMPETENCE

\begin{tabular}{|l|c|}
\hline \multicolumn{1}{|c|}{$\begin{array}{c}\text { Area of IPMA-Student } \\
\text { competence }\end{array}$} & $\begin{array}{c}\text { Average percentage of correct } \\
\text { answers }\end{array}$ \\
\hline $\begin{array}{l}1.0 \text { Technical competence } \\
\text { elements }\end{array}$ & $58,63 \%$ \\
\hline $\begin{array}{l}2.0 \text { Behavioural competence } \\
\text { elements }\end{array}$ & $76,14 \%$ \\
\hline $\begin{array}{l}\text { 3.0 Contextual competence } \\
\text { elements }\end{array}$ & $55,95 \%$ \\
\hline Source: Own elaboration based on materials of the IPMA-Student
\end{tabular}

Source: Own elaboration based on materials of the IPMA-Student Programme.

By studying strong and weak areas of students' knowledge, the results obtained during the eExamination were analysed in particular areas of IPMA competence (Table 3) and then in particular competence elements (Table 4, Table 5, Table 6). It is worth noting that the IPMA-Student Model places the greatest emphasis on technical competence in project management. Technical competence covers $70 \%$ of all competence, whereas behavioural and contextual elements: $15 \%$ each. The examination structure reflects the structure of the IPMA-Student Model.

The results in the area of behavioural competences are statistically significantly better than in other areas (Table 3). The least developed are contextual 
competences, which seems to be understandable, given the lesser practical experience of students.

TABLE IV. INDICATOR OF CORRECT ANSWERS TO QUESTIONS IN PARTICULAR AREAS OF IPMA TECHNICAL COMPETENCE

\begin{tabular}{|l|c|}
\hline \multicolumn{1}{|c|}{$\begin{array}{c}\text { IPMA-Student } \\
\text { competence elements }\end{array}$} & $\begin{array}{c}\text { Average percentage of correct } \\
\text { answers }\end{array}$ \\
\hline $\begin{array}{l}\text { 1.01 Project management } \\
\text { success }\end{array}$ & $68,69 \%$ \\
\hline 1.02 Interested parties & $70,69 \%$ \\
\hline $\begin{array}{l}\text { 1.03 Project requirements } \\
\text { and objectives }\end{array}$ & $69,49 \%$ \\
\hline 1.04 Risk and opportunity & $33,85 \%$ \\
\hline 1.05 Quality & $44,92 \%$ \\
\hline 1.06 Project organisation & $66,97 \%$ \\
\hline 1.07 Teamwork & $56,90 \%$ \\
\hline 1.08 Problem resolution & $80,52 \%$ \\
\hline 1.09 Project structures & $52,41 \%$ \\
\hline $\begin{array}{l}\text { 1.10 Scope and } \\
\text { deliverables }\end{array}$ & $48,14 \%$ \\
\hline $\begin{array}{l}\text { 1.11 Time and project } \\
\text { phases }\end{array}$ & $45,17 \%$ \\
\hline 1.12 Resources & $63,91 \%$ \\
\hline 1.13 Cost and Finance & $67,64 \%$ \\
\hline 1.15 Changes & $60,34 \%$ \\
\hline 1.16 Control and reports & $71,24 \%$ \\
\hline 1.18 Communication & materials of the IPMA-Student \\
\hline $\begin{array}{l}\text { Source: Own elaboration based } \\
\text { Programme. }\end{array}$ & \\
\hline
\end{tabular}

Within the technical competence area, communication competence elements are best developed and risks - least developed.

In the area of behavioural competences, students gave best answers to the questions about engagement and motivation, whereas the worst answers in leadership.

TABLE V. INDICATOR OF CORRECT ANSWERS TO QUESTIONS IN PARTICULAR AREAS OF IPMA BEHAVIOURAL COMPETENCE

\begin{tabular}{|l|c|}
\hline \multicolumn{1}{|c|}{$\begin{array}{c}\text { IPMA-Student } \\
\text { competence elements }\end{array}$} & $\begin{array}{c}\text { Average percentage of correct } \\
\text { answers }\end{array}$ \\
\hline 2.01 Leadership & $57,93 \%$ \\
\hline $\begin{array}{l}\text { 2.02 Engagement and } \\
\text { motivation }\end{array}$ & $97,76 \%$ \\
\hline 2.04 Assertiveness & $94,48 \%$ \\
\hline 2.07 Creativity & $72,64 \%$ \\
\hline 2.08 Results orientation & $91,38 \%$ \\
\hline 2.12 Conflict and crisis & $53,28 \%$ \\
\hline 2.13 Reliability & $90,69 \%$ \\
\hline 2.14 Values appreciation & $81,03 \%$ \\
\hline 2.15 Ethics & $90,69 \%$ \\
\hline Source: Own elaboration based on materials of the IPMA-Student
\end{tabular}

Programme.
Contextual competences are most developed in the area of personnel management, and the weakest in project orientation. This can be explained by the relatively high number of didactic hours devoted to human resources management.

TABLE VI. INDICATOR OF CORRECT ANSWERS TO QUESTIONS IN PARTICULAR AREAS OF IPMA CONTEXTUAL COMPETENCE

\begin{tabular}{|l|c|}
\hline \multicolumn{1}{|c|}{$\begin{array}{c}\text { IPMA-Student } \\
\text { competence elements }\end{array}$} & $\begin{array}{c}\text { Average percentage of correct } \\
\text { answers }\end{array}$ \\
\hline 3.01 Project orientation & $49,92 \%$ \\
\hline $\begin{array}{l}\text { 3.05 Permanent } \\
\text { organisation }\end{array}$ & $52,13 \%$ \\
\hline $\begin{array}{l}\text { 3.08 Personal } \\
\text { management }\end{array}$ & $65,38 \%$ \\
\hline $\begin{array}{l}\text { Source: Own elaboration based on materials of the IPMA-Student } \\
\text { Programme. }\end{array}$
\end{tabular}

\section{CONCLUSIONS}

The research carried out based on the results of the certification of students of Polish universities within the IPMA-Student Programme indicates that:

In the analysed group, individual areas of project management competence are not equally developed.

The least developed are contextual competences in project management, while the highest are behavioural competences.

All elements of behavioural competences are developed at a high level of over 50\% (IPMA Student pass mark),

The development of contextual competences requires support, especially in the area of project orientation; results are below the threshold of $50 \%$ of correct answers.

Within technical competences, the least developed area competences related to risk, the highest are those related to communication. Some of the competence elements are below the level of $50 \%$ of correct answers, which should be the improvement area.

The average exam score is above $50 \%$ of correct answers.

The IPMA-Student programme is an objective system for the verification of students' competences, the only one in Poland that has been accepted and implemented by more than a dozen higher education institutions in Poland. It is independent of the field of study and the level of quality of education. The results obtained by the students are comparable, regardless of the university where the students improved their competences.

\section{REFERENCES}

[1] L. Crawford, "Senior management perceptions of project management competence", International Journal of Project Management, Volume 23, Issue 1, January 2005, pp. 7-16.

[2] Manpower, "Solving the Talent Shortage Build, Buy, Borrow and Bridge", 2018.

[3] R. E. Boyatzis, "The competent manager: A model for effective performance", Wiley, New York, 1982, pp. 21. 
[4] L. M. Spencer, and S. M. Spencer, "Competence at work: models for superior performance", Wiley, New York, 1993, pp. 9-11.

[5] D. D. Dubois, and W. J. Rothwell, "Competence-based human resources management","Zarządzanie zasobami ludzkimi oparte na kompetencjach", Publishing Helion, Gliwice, 2008, pp. 32.

[6] T. Oleksyn, "Competence management, theory and practice", "Zarządzanie kompetencjami Teoria i praktyka", Oficyna a Wolters Kluwer business, Warszawa, 2010, pp. 93.

[7] M. Spychała, and M. Matejun, "Students' Assessment of Selected Management Competences", "Badanie ocen wybranych kompetencji menedżerskich studentów", WOiZ Politechniki Łódzkiej, Marketing i Rynek, nr 05, 2015, pp. 1278.

[8] A. Dehghanpour Farashah, J. Thomas, and T. Blomquist, "Exploring the value of project management certification in selection and recruiting", International Journal of Project Management, vo. 37, 2019, pp. 14-15.

[9] ICB IPMA Competence Baseline Version 3.0, 2006, pp. 6. 